\title{
Withering and the foxglove: the making of a myth
}

\author{
DENNIS M KRIKLER \\ From the Cardiovascular Division, Royal Postgraduate Medical School, Hammersmith Hospital, London
}

The bicentennial celebrations are prompted not by Withering's original observation of the clinical value of digitalis in 1775 but rather by the publication of his detailed report 10 years later. This book is the source of the information on how he came to learn of digitalis. ${ }^{1}$ As indicated elsewhere, ${ }^{2}$ the circumstances of his encounter with digitalis could not be more clearly set out, and alternative explanations seem redundant. Peck and Wilkinson ${ }^{3}$ surmised that Withering's interest in digitalis arose after he had moved from Stafford to Birmingham, during the period when he returned to Stafford each week to keep an eye on patients until his successor arrived. They speculated that he had encountered a patient with dropsy, and that on a subsequent journey he inquired after her and discovered that she had done remarkably well on secret herbs. There is however no prior reference to justify this statement, which can be looked upon as a harmless speculation. Roddis ${ }^{4}$ had earlier recounted the story in exactly the terms used by Withering, but several years before this an alternative explanation had been created. The origin of this vivid account has been difficult to track down, and the story entered medical awareness as the introductory note by Willius and Keys to their extract ${ }^{5}$ from Withering's book An Account of the Foxglove. ${ }^{1}$

Where did Willius and Keys derive their information? They clearly state that the picture that they published was an imaginative rendering, as indeed it must have been, for it is said to depict Withering at the time of his "discovery" of digitalis (Figure), but in 1775 he was 34 years old, and in sound health; his chronic lung disease only became apparent 8 or 9 years later. Willius and Keys attributed the picture to Parke, Davis and Company, but the original painting is no longer in their collection, nor could it be found in the Detroit Historical Museum or in the Burton Collection at the Detroit Public Library (J A Callahan, N Hensel, and H B Burchell, personal communication). Direct enquiries to Parke-Davis, now a division of the Warner-Lambert Company, did not at first yield the answer, but one of their senior staff soon chanced

Requests for reprints to Dr Dennis Krikler, Cardiovascular Division, Royal Postgraduate Medical School, Hammersmith Hospital, Ducane Road, London W12 0HS. upon a stack of 250 pictures of advertisements used by them between the late 1920 s and the 1940 s, only 100 feet from his office (J A Controulis, personal communication). The picture shown in the Figure is the 23rd in the series and was painted by Will Meade Prince in 1928 or 1929; while many in the set carry his signature in the lower right hand corner, this had been removed from the present picture as well as some others to provide what was considered to be an "appropriate fit for the advertising copy".

The enthusiastic text that accompanied the picture is of almost as much interest as the creation of the scene. Perhaps Will Meade Prince felt entitled to $\overrightarrow{0}$ make Withering look older because he was under the of impression that his scientific discovery was made in 1785 , but even then he would have been only 44 . He is said to be handing over "golden sovereigns for the secret of the wayside flower" to Old Mother Hutton, a "Shropshire herb-woman" who had guarded her secret jealously. Correctly, they mentioned the fact that digitalis had previously proved helpful when given to the Dean of Brazen Nose College, Oxford, for his dropsy. Though Withering himself mentions 20 or more herbs, the advertisement refers to 12 . Though Withering, an expert botanist, had indicated that by glancing at the prescription he could see that the foxglove must have contained the only possible active substance, ${ }^{1}$ the advertisement more dramatically claimed that "after long and patient trial he found 11 of them medicinally worthless. But from the twelfth, the purple foxglove, he obtained a powerful new $\subseteq$ drug ... digitalis."

Thus the name Old Mother Hutton, the creation of a copywriter, has crept in and become linked with the $N$ discovery of the medicinal properties of digitalis, and an interesting anecdote turns out to be an embellish- $\mathcal{O}_{N}$ ment rather than an improvement on the story as $\omega$ given by Withering. ${ }^{1}$

A relevant sidelight: soon after Parke, Davis \& Company ran their series of historical advertisements, one of the original members of their present parent $\stackrel{+}{-}$ organisation, William $\mathbf{R}$ Warner \& Company, $\frac{0}{0}$ adorned their physicians' diary with historical foot- $\frac{\vec{D}}{\mathbb{D}}$ notes that provided many with their first exposure to $\frac{\rho}{\Phi}$ famous names and events in medicine and surgery. 


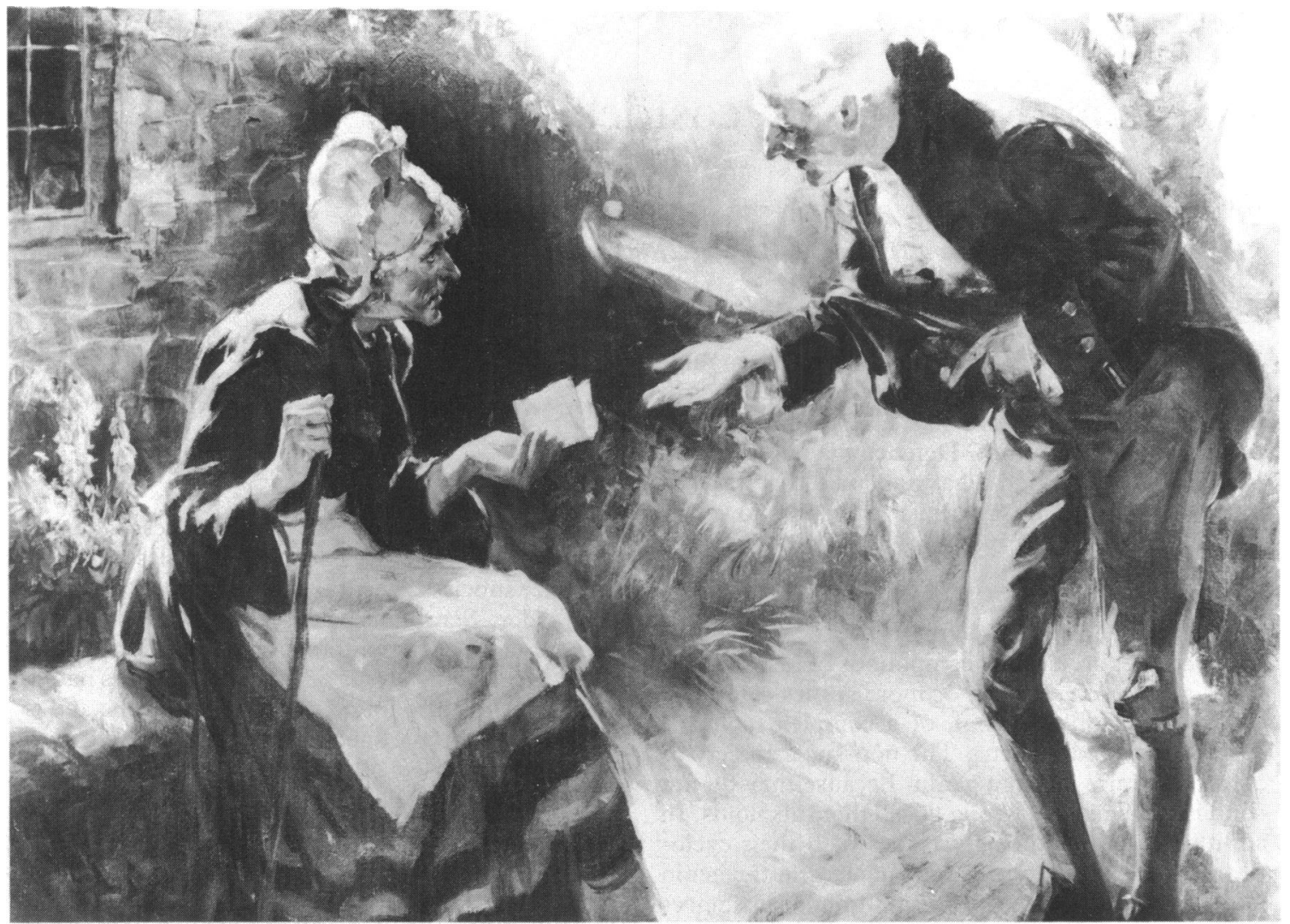

Figure Depiction by Will Meade Prince of William Withering exchanging golden sovereigns for the "secret recipe" held by "Old Mother Hutton" (published with acknowledgement to Parke-Davis, Morris Plains, New fersey).

\section{References}

1 Withering W. An account of the foxglove, and some of its medical uses: with practical remarks on dropsy, and other diseases. London: G G J and J Robinson, 1785: 2.

2 Krikler DM. The foxglove, "The Old Woman from Shropshire" and William Withering. $\mathcal{F}$ Am Coll Cardiol 1985; 5: 3A-9A.

3 Peck TW, Wilkinson KD. William Withering of Biming- ham MD, FRS, FLS. Bristol: John Wright \& Sons, 1950: 70.

4 Roddis LH. William Withering and the introduction of digitalis into medical practice. Fournal of the American Pharmaceutical Association 1936; 25: 38-40.

5 Willius FA, Keys TE, eds. Cardiac classics. A collection of classic works on the heart and circulation with comprehensive biographic accounts of the authors: 52 contributions by 51 authors. St Louis; C V Mosby, 1941: 228. 